\title{
Ammonia volatilization from nitric-acid-treated cattle slurry surface applied to grassland
}

\section{D.W. BUSSINK ${ }^{1}$, J.F.M. HUIJSMANS ${ }^{2}$ AND J.J.M.H. KETELAARS ${ }^{3}$}

I Nutrient Management Institute (NMI), Research Institute for Cattle, Horse and Sheep Husbandry, Runderweg 6, NL-8219 PK Lelystad, The Netherlands

2 DLO Institute of Agricultural and Environmental Engineering (IMAG-DLO), P.O. Box 43, NL-6700 AA Wageningen, The Netherlands

3 DLO Research Institute for Agrobiology and Soil Fertility (AB-DLO), P.O. Box 14, NL-6700 AA Wageningen, The Netherlands

Received 24 March 1994; accepted 2 September 1994

\begin{abstract}
Much research is being done to lower $\mathrm{NH}_{3}$ volatilization from animal manure. In this study, reduction in $\mathrm{NH}_{3}$ loss from $\mathrm{HNO}_{3}$ treated cattle slurry, surface applied to grassland, was measured on different soil types throughout the Netherlands from 1989 to 1992 . In total, 13 micro-meteorological mass balance and 10 small wind tunnel experiments were carried out. Amounts varying between $7-17$ and $10-30 \mathrm{~m}^{-3} \mathrm{ha}^{-1}$ were applied, respectively. Measurements were performed for 4 and 10 days, respectively. The pH of treated slurry ranged from 3.9 to 6.6. Acidified slurry was always compared with untreated slurry.

A mean total of $60 \%$ (range: $29-98 \%$ ) of the $\mathrm{NH}_{4}-\mathrm{N}$ from untreated slurry was volatilized in the mass balance experiments. A reduction in $\mathrm{NH}_{3}$ volatilization of 85,72 and $55 \%$ was achieved for acidified slurry with a respective pH of c. $4.5,5.0$ and 6.0. Approximately $55 \%$ (range: 7-91\%) of the total loss from acidified slurry was measured on the day of application. A mean total of $66 \%$ (range: $21-90 \%$ ) of $\mathrm{NH}_{4}-\mathrm{N}$ from untreated slurry volatilized in the tunnel experiments. The reduction in $\mathrm{NH}_{3}$ volatilization was $73 \%$ for slurry with pH 4.5 . Approximately $27 \%$ (range: $6-91 \%)$ of the total loss from acidified slurry was measured on the first day. The lower reduction and the different pattern in $\mathrm{NH}_{3}$ volatilization observed in the wind tunnel experiments might be the consequence of different climatic conditions in and outside the tunnels or they might be related to the higher rates of slurry application in these experiments.

Regression analysis indicated that high temperature, slurry $\mathrm{pH}$, potential water evaporation and $\mathrm{NH}_{4}^{+}$concentration stimulated $\mathrm{NH}_{3}$ loss in the mass balance experiments $\left(\mathrm{R}^{2}=\right.$ $87 \%$ ). It is suggested that the results obtained with acidified slurry were independent of the grassland soil type at the application levels employed.
\end{abstract}

Keywords: ammonia volatilization, cattle slurry, acidification, nitric acid, grassland, $\mathrm{pH}$

\section{Introduction}

Livestock excreta are generally regarded as the main source of $\mathrm{NH}_{3}$ input into the atmosphere (Apsimon et al., 1987; Schlesinger \& Hartley, 1992). Losses may arise 


\section{D.W. BUSSINK, J.F.M. HUIJSMANS AND J.J.M.H. KETELAARS}

from grazing, housed livestock, slurry storage units and (surface) applied slurry. In Europe the largest losses are considered to result from surface applied slurry (Buijsman et al., 1987); ranging between 20 to $85 \%$ of the $\mathrm{NH}_{4}-\mathrm{N}$ applied (Bless et al. 1991; Pain et al. 1989; Sommer et al. 1991). The large variation is due to differences in soil type, amount and composition of slurry (Sommer \& Olesen 1991) and environmental conditions (Horlacher \& Marschner, 1990; Sommer et al. 1991).

Decreasing $\mathrm{NH}_{3}$ losses will improve the $\mathrm{N}$ fertilizer value of land-applied slurry and decrease the impact of $\mathrm{NH}_{3}$ on eutrophication and acid deposition (Roelofs et $a l ., 1985)$. Slurry injection and soil tillage immediately after surface application on arable land (Van der Molen et al. 1990; Horlacher \& Marschner, 1990; Bless et al. 1991; Mulder \& Huijsmans 1994) and slurry injection on grassland (Van der Meer et al., 1987; Thompson et al. 1987; Bussink \& Bruins, 1992; Mulder \& Huijsmans, 1994) proved to be efficient methods in reducing $\mathrm{NH}_{3}$ losses. Because of the heavy application machinery and high draft requirement, injection on grassland is limited to light stone-free soils with a high bearing capacity. Under such conditions dilution of slurry or water irrigation after surface application (Sommer \& Olesen, 1991; Bussink \& Bruins, 1992) and band-spreading (Mulder \& Huijsmans, 1994) are useful techniques.

Acidification of slurry has also shown great potential in reducing of $\mathrm{NH}_{3}$ losses (Stevens et al., 1989; Frost et al., 1990; Pain et al., 1990). A key factor in the reduction of $\mathrm{NH}_{3}$ losses is slurry $\mathrm{pH}$ at application (Stevens et al., 1992).

In the Netherlands much research has been done with respect to $\mathrm{NH}_{3}$ loss reducing potential, the technical implementation in practice, the economics and the environmental aspects of nitric-acid-treated cattle slurry. This study examines the $\mathrm{NH}_{3}$ losses from acidified cattle slurry surface-applied on grassland. Nitric acid $\left(\mathrm{HNO}_{3}\right)$ was chosen because the anion is a valuable plant nutrient and by varying the amount of $\mathrm{HNO}_{3}$ applied it is possible to meet the total $\mathrm{N}$ demand of grass. However, this will lead to variations in slurry $\mathrm{pH}$ and thus in $\mathrm{NH}_{3}$ losses. Therefore the main emphasis was placed on the effect of slurry $\mathrm{pH}$ and $\mathrm{NH}_{4}^{+}$activity on $\mathrm{NH}_{3}$ volatilization and on changes in slurry $\mathrm{pH}$ after application. Results from four years of experimentation, using the micro-meteorological mass balance method and small wind tunnels at various sites and environmental conditions are described. The results were used to predict $\mathrm{pH}$ requirement for target volatilization reduction levels.

\section{Materials and methods}

\section{Theory of $\mathrm{NH}_{3}$ volatilization}

Up to $80 \%$ of the mineral $\mathrm{N}$ in slurry originates from urea, which rapidly hydrolyses into $\left(\mathrm{NH}_{4}\right)_{2} \mathrm{CO}_{3}$. The $\mathrm{NH}$ in the slurry is in equilibrium with $\mathrm{NH}_{3}$ in the liquid and gas phases according to:

$$
\mathrm{NH}_{4(\mathrm{aq})}^{+}+\mathrm{H}_{2} \mathrm{O} \rightleftarrows \mathrm{NH}_{3(\mathrm{aq})}+\mathrm{H}_{3} \mathrm{O}^{+} \text {with } K_{\alpha}=\frac{\left(\mathrm{NH}_{3}\right)_{\mathrm{aq}}\left(\mathrm{H}^{+}\right)}{\left(\mathrm{NH}_{4}^{+}\right)_{\mathrm{aq}}}
$$




$$
\mathrm{NH}_{3(\mathrm{aq})} \rightleftarrows \mathrm{NH}_{3(\mathrm{~g})} \text { with } \mathrm{H}=\frac{\left(\mathrm{NH}_{3}\right)_{\mathrm{g}}}{\left(\mathrm{NH}_{3}\right)_{\mathrm{aq}}}
$$

where (..) $)_{a q}$ and (..) $)_{g}$ are the activity $(M)$ of the species in solution and in air, respectively; $K_{a}$ is the dissociation constant $(\mathrm{M})$ and $\mathrm{H}$ is the Henry constant $\left(\mathrm{M} \mathrm{M}^{-1}\right) . \mathrm{K}_{\mathrm{a}}$ and $\mathrm{H}$ are temperature $\left(\mathrm{T},{ }^{\circ} \mathrm{C}\right)$ dependent. Using the temperature corrections of Emerson et al. (1975) for $K_{g}$ and of Dasgupta \& Dong (1986) for H/RT $=K_{h}$ (M $\mathrm{atm}^{-1}$, with $\mathrm{atm}=1.103 * 10^{5} \mathrm{~Pa}$ ) and rewriting Equations (1) and (2) gives:

$$
\left(\mathrm{NH}_{3}\right)_{\mathrm{g}}=\frac{K_{a}\left(\mathrm{NH}_{4}\right)_{\mathrm{aq}}}{K_{h}\left(\mathrm{H}^{+}\right)}=\left(\mathrm{NH}_{4}\right)_{\mathrm{aq}} 10^{(4.117+\mathrm{pH}-4507.053 /(\mathrm{T}+273.15))}
$$

By lowering the $\mathrm{pH}$ of the solution $\left(\mathrm{NH}_{3}\right)_{\mathrm{g}}$ decreases and thereby so does the potential for $\mathrm{NH}_{3}$ losses. The relationship between $\left(\mathrm{NH}_{3}\right)_{3}, \mathrm{pH}$ and $\mathrm{T}$ is shown in Figure. 1. For a slurry of average ionic strength $(I)$ of $0.3 \mathrm{M}$ and $2.2 \mathrm{~kg} \mathrm{NH}_{4}-\mathrm{N} \mathrm{m}^{-3}$, $\left(\mathrm{NH}_{4}\right)_{\mathrm{aq}}$ is $0.108 \mathrm{M}$ (Vanysek, 1989), neglecting adsorption and complex formation. Lowering the $\mathrm{pH}$ from 7.5 to 4.5 gives a sharp decrease in $\left(\mathrm{NH}_{3}\right)_{\mathrm{g}}$ to values below background level in the atmosphere i.e. $5-25 \mu \mathrm{g} \mathrm{NH}_{3}-\mathrm{N} \mathrm{m}^{-3}$ in our experiment. Due to water evaporation, I and $\left(\mathrm{NH}_{4}\right)_{\mathrm{aq}}$ will increase. At a relative humidity of $75 \%$, the osmotic pressure of the slurry will rise to $-38 \mathrm{MPa}$ before evaporation ceases (calculated according to Koorevaar et al. 1983). This agrees with $\mathrm{I}=8.0 \mathrm{M}$, assuming a

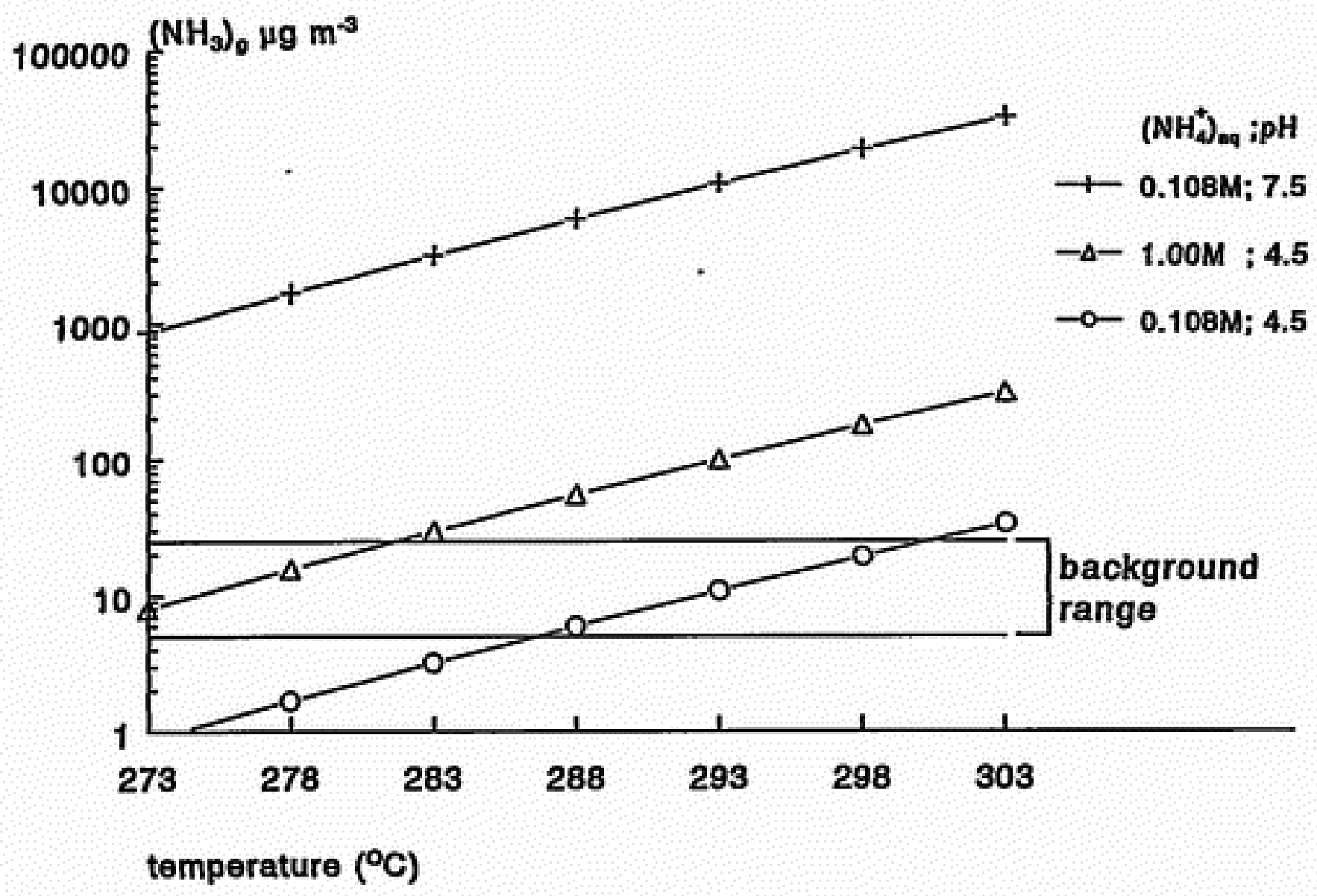

Figure 1. Equilibrium $\left(\mathrm{NH}_{3}\right)_{\mathrm{g}}$ concentration in air for a solution with $\mathrm{NH}_{4}^{+}$activity, $\left(\mathrm{NH}_{4}\right)$ of 0.108 and $1.0 \mathrm{M}$ at different temperatures and solution pH's (1.0 M as example of the effect of water evaporation); background $\left(\mathrm{NH}_{3}\right)_{\mathrm{g}}$ range from 5 to $25 \mu \mathrm{g} \mathrm{m}^{-3}$. 
complete dissolution of the salts. As a consequence $\left(\mathrm{NH}_{4}^{+}\right)_{\mathrm{aq}}$ and $\left(\mathrm{NH}_{3}\right)_{\mathrm{g}}$ increase and, hence, $\mathrm{NH}_{3}$ is released (Figure 1). In theory due to evaporation, there may be $\mathrm{NH}_{3}$ volatilization at $\mathrm{pH}$ values as low as 4.5.

\section{Description of sites and experimental treatments}

Two separate data sets were available to analyse the effects of slurry acidification. One set of volatilization data had been obtained using the micro-meteorological mass balance method (Denmead, 1983) the other set using wind tunnel measurements (Lockyer, 1984).

All data originated from field experiments carried out at 5 sites, on clay soils near Swifterbant and Duiven, peat soil in Zegveld and sandy soils in Luttenberg and Wageningen. The location and soil characteristics of the sites are shown in Table 1. The well established swards contained perennial ryegrass as dominant grass species and had been intensively managed in previous years. In all experiments untreated cattle slurry was compared with $\mathrm{HNO}_{3}$ treated cattle slurry at similar levels of slurry application. Wind speed, air temperature at $1.5 \mathrm{~m}$, humidity and sunshine duration and radiation were recorded on all sites. Water evaporation data for the sites were obtained from the meteorological office.

In the experiments using the mass balance method, slurry was surface applied before noon using a tanker fitted with a splash plate. Working width varied between 2.5 and $8 \mathrm{~m}$. By spreading in parallel passes varying in length over a pre-marked area, circular plots were achieved with a radius varying between 20 and $24 \mathrm{~m}$. The $\mathrm{pH}$ of the acidified slurry ranged from 3.9 to 6.6 .

In the experiments using small wind tunnels slurry was applied with a watering can. The pH of the acidified slurry was c. 4.5 .

\section{Measurement of $\mathrm{NH}_{3}$ losses by mass balance}

The micro-meteorological mass balance method assumes that the vertically integrated product of wind speed and the difference in air- $\mathrm{NH}_{3}$ concentration, between the

Table 1. Location of the sites and characteristics of the $0-5 \mathrm{~cm}$ soil layer.

\begin{tabular}{|c|c|c|c|c|c|c|c|c|}
\hline & \multicolumn{2}{|l|}{ location } & \multirow{2}{*}{$\begin{array}{l}\text { soil } \\
\text { type }\end{array}$} & \multirow[t]{2}{*}{$\mathrm{pH}-\mathrm{KCl}$} & \multirow{2}{*}{$\begin{array}{l}\mathrm{CEC} \\
\mathrm{mol}_{\mathrm{c}} \mathrm{kg}^{-1} \\
\%\end{array}$} & \multirow{2}{*}{$\begin{array}{l}\text { organic } \\
\text { matter }\end{array}$} & \multirow{2}{*}{$\begin{array}{l}\mathrm{CaCO}_{3} \\
\% \\
\%\end{array}$} & \multirow{2}{*}{$\begin{array}{l}\text { clay } \\
<2 \mu m\end{array}$} \\
\hline & longitude & latitude & & & & & & \\
\hline Zegveld & $452^{\prime}$ & $5207^{\prime}$ & peat & 4.9 & 0.24 & 45.1 & 0 & - \\
\hline Luttenberg & $621^{\prime}$ & $5223^{\prime}$ & sand & 5.3 & - & 5.7 & 0 & - \\
\hline Duiven & $601^{\prime}$ & $5156^{\prime}$ & $\begin{array}{l}\text { heavy } \\
\text { clay }\end{array}$ & 5.2 & - & 13.7 & 0 & 44 \\
\hline Wageningen & $540^{\prime}$ & $5159^{\prime}$ & sand & 5.0 & 0.04 & 3.2 & 0 & - \\
\hline Swifterbant & $540^{\prime}$ & $5235^{\prime}$ & clay & 6.9 & 0.28 & $8.1^{\circ}$ & 6.4 & 18 \\
\hline
\end{tabular}

* corrected for $\mathrm{CaCO}_{3}$ 
centre and boundary of the plot, divided by the fetch (distance between upwind boundary and the centre of the plot) is equal to the $\mathrm{NH}_{3}$ flux from the soil surface (Denmead, 1983).

As soon as the first half of the circular plots was covered with slurry (usually within 5 minutes) a mast supporting 7 to $8 \mathrm{NH}_{3}$ traps at heights between 0.25 and $3.30 \mathrm{~m}$ was placed in the centre of the plot. At the windward boundary of the plot, a mast was placed with $5 \mathrm{NH}_{3}$ traps at heights between 0.40 and $2.30 \mathrm{~m}$. Fewer traps were placed at the boundary because the background concentration was low and essentially uniform with height. Each trap contained $20 \mathrm{ml} 0.02 \mathrm{M} \mathrm{H}_{3} \mathrm{PO}_{4}$ or $0.02 \mathrm{M}$ $\mathrm{HNO}_{3}$ held in $100 \mathrm{ml}$ collection tubes. Air was drawn through the acid via a sintered gas dispersion tube at rates of 2-41 min-1, measured with flow meters. A correction was made for the measured pressure drop between the flow meter and the air inlet of the trap.

The measurements continued for at least 4 days after slurry application. Traps were replaced five times in the first $24 \mathrm{~h}$ when the highest $\mathrm{NH}_{3}$ loss rates occurred. From day 2 to day 4 the traps were replaced in early morning and late afternoon. Wind speed was measured on a mast outside the plot, at six different heights, between 0.40 and $3.30 \mathrm{~m}$. A total of 13 experiments were conducted (see Table 2 for details).

\section{Measurement of $\mathrm{NH}_{3}$ losses by wind tumnels}

The design of the small wind tunnels followed essentially the description by Lockyer (1984). A U-shaped transparent tunnel of polycarbonate covers an experimental plot $(2.0 \times 0.5 \mathrm{~m})$. The tunnel is connected to a circular steel duct housing an electrically powered fan. In principle the method consists of sampling a controlled airflow (generated by the fan) before and after it passes over the experimental plot in the tunnel. The difference in concentration between inlet and outlet multiplied by the airflow and corrected for the experimental area is equal to the $\mathrm{NH}_{3}$ flux for a certain measurement period.

The $\mathrm{NH}_{3}$ concentrations in inlet and outlet of the tunnel were measured by drawing air continuously via a sintered gas dispersion tube at a rate of $131 \mathrm{~min}^{-1}$ through $0.3 \mathrm{M} \mathrm{H}_{3} \mathrm{PO}_{4}$ held in $100 \mathrm{ml}$ collection tubes. These traps were usually replaced on a $24 \mathrm{~h}$ basis during a 10-day measurement period. Air passed through the tunnel at rates of $2 \mathrm{~m} \mathrm{~s}^{-1}$ in two experiments and $1 \mathrm{~m} \mathrm{~s}^{-1}$ in the other eight experiments (see Table 3 for details).

\section{Analytical methods}

The $\mathrm{NH}_{4}^{+}$concentration in the $\mathrm{H}_{3} \mathrm{PO}_{4}$ solutions was measured colorometrically (Weatherburn, 1967; Bietz, 1974), whereas ion-chromatography was used for analysis of the $\mathrm{NH}_{4}^{+}$concentration in the $0.02 \mathrm{M} \mathrm{HNO}_{3}$ solution.

In the mass balance experiments 12 and 13 and in the tunnel experiments $4,6,8$ and 10 slurry surface $\mathrm{pH}$ was measured after application using a flat-surface combined glass electrode after moistening the slurry with dionized water. Per plot three readings were obtained during the course of the experiment. 


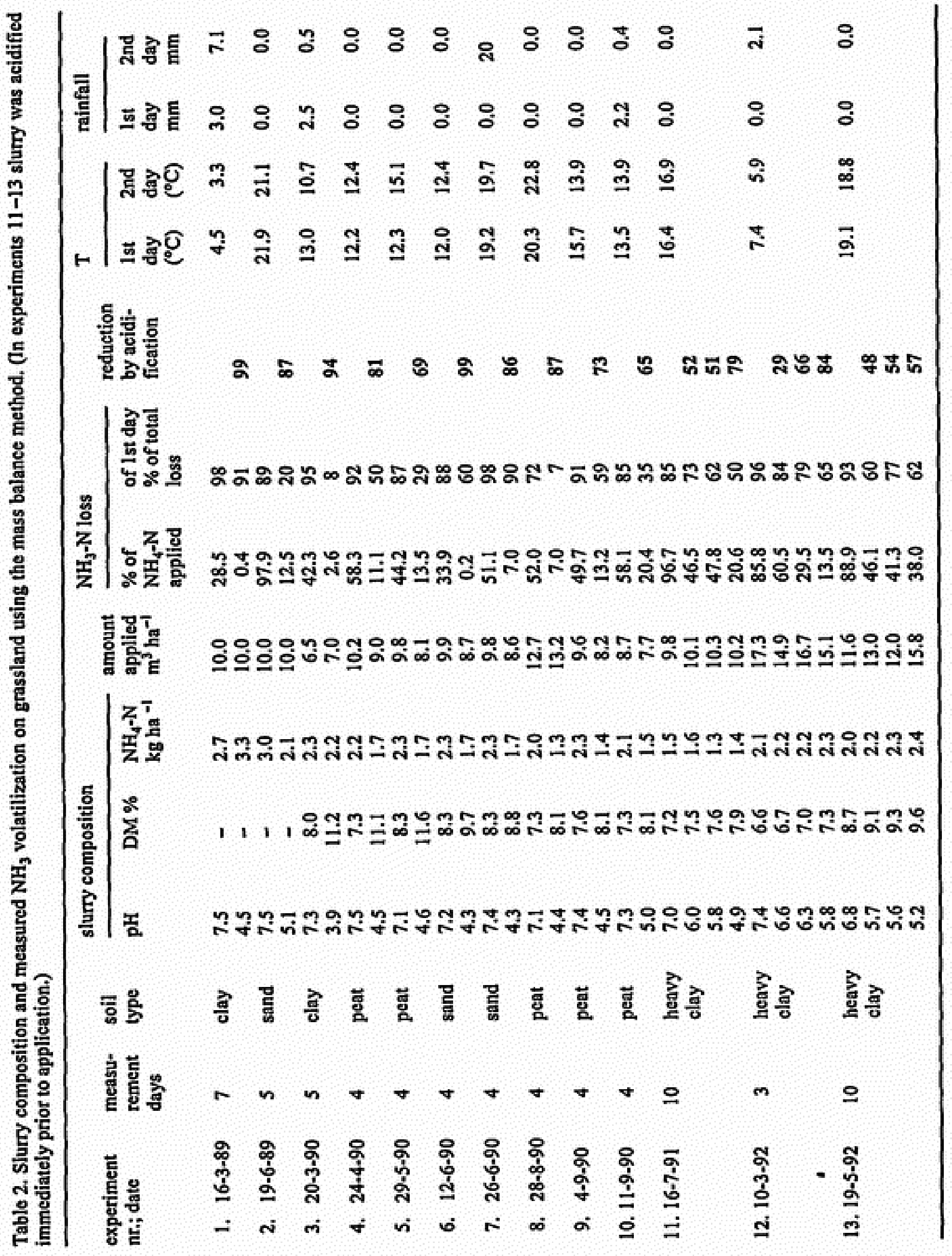




\section{Results}

$\mathrm{NH}_{3}$ losses from untreated slurry

The mass balance measurements showed a high $\mathrm{NH}_{3}$ loss rate from untreated slurry during the first hours after application (Figure 2). The average total $\mathrm{NH}_{3}$ loss was $60 \%$ (range: $29-98 \%$ ) of the $\mathrm{NH}_{4}-\mathrm{N}$ applied at an average slurry application of 10.4 (range: $6.5-17.3$ ) $\mathrm{m}^{3} \mathrm{ha}^{-1}$ (Table 2). On average 90\% (range: $72-98 \%$ ) of the total losses were measured on the first day after application. One day after application the rate of loss decreased sharply.

Results obtained with the tunnel method were comparable to those obtained with the mass balance method. Total average loss was $66 \%$ (range: $21-90 \%$ ) of the $\mathrm{NH}_{4}-\mathrm{N}$ applied (Table 3) at an average slurry application of 24.1 (range: 9.9-30) $\mathrm{m}^{3}$ $\mathrm{ha}^{-1}$. On average $60 \%$ (range: $44-94 \%$ ) of the total $\mathrm{NH}_{3}$ loss was measured on the first day. Hence, volatilization continued longer in the tunnel than in the mass balance experiments (e.g. Figures 2 and 3 ).

\section{$\mathrm{NH}_{3}$ losses from acidified slurry}

The mass balance experiments gave a reduction in $\mathrm{NH}_{3}$ volatilization for acidified slurry of 29 up to $99 \%$ of that found with untreated slurry. Ammonia volatilization was strongly related to slurry $\mathrm{pH}$ (Table 2). A mean reduction in $\mathrm{NH}_{3}$ volatilization of 85,72 and $55 \%$ was achieved for acidified slurry with a respective pH of c. 4.5 , 5.0 and 6.0. The $\mathrm{NH}_{3}$ loss from acidified slurry was very low in the first hours after application, but increased later. On average, $55 \%$ (range: 7-91\%) of the total $\mathrm{NH}_{3}$ loss was measured on the first day with application rates averaging 10.8 (range: 7.0-16.7) $\mathrm{m}^{3} \mathrm{ha}^{-1}$. The percentage of $\mathrm{NH}_{4}-\mathrm{N}$ volatilized (\% $\mathrm{NH}_{4}$-loss) on the first day was strongly related to initial $\left(\mathrm{NH}_{3}\right)_{\mathrm{g}}$ (Equation 3; using the initial slurry $\mathrm{pH}$, the average temperature of the first day at $1.5 \mathrm{~m}$ and using the initial $\mathrm{NH}_{4}^{+}$concentration instead of $\mathrm{NH}_{4}^{+}$activity) and soil type according to:

$$
\begin{aligned}
\% \mathrm{NH}_{4} \text {-loss }= & 5.42( \pm 0.77) \times 10^{7}\left(\mathrm{NH}_{3}\right)_{\mathrm{g}}+4.25( \pm 2.03) \times \text { peat }+10.44( \pm 2.74) \\
& \times \text { (heavy clay) }
\end{aligned}
$$

with: $R^{2}{ }_{\text {adj }}=90.5 \%$ and $n=19$ (all treated slurries of Table 2)

It was tested that clay and sandy soil did not differ from each other. Peat and heavy clay showed higher volatilization rates for the same $\left(\mathrm{NH}_{3}\right)_{\mathrm{g}}$ than clay and sandy soil. Inclusion of (wind speed) $\times\left(\mathrm{NH}_{3}\right)_{\mathrm{g}}$, (water evaporation) $\times\left(\mathrm{NH}_{3}\right)_{\mathrm{g}}$ or (application level) $\times\left(\mathrm{NH}_{3}\right)_{\mathrm{g}}$ did not improve $\mathrm{R}_{\text {adj. }}^{2}$. The total percentage of $\mathrm{NH}_{4}-\mathrm{N}\left(\% \mathrm{TNH}_{4}\right.$-loss) volatilized during the experimental period was strongly related to initial $\left(\mathrm{NH}_{3}\right)_{\mathbf{g}}$, soil type and 4-day cumulative water evaporation ( $\operatorname{cumE}_{\mathrm{p}} 4, \mathrm{~mm}$ ), according to:

$$
\begin{aligned}
& \%_{\mathrm{TNH}_{4}} \text {-loss }=\left(3.61( \pm 1.68)+1.58( \pm 0.86) \times \text { cumE }_{\mathrm{p}} 4\right) \times 10^{7}\left(\mathrm{NH}_{3}\right)_{\mathrm{g}}+12.09 \\
& ( \pm 2.96) \times \text { peat }+17.87( \pm 4.24) \times(\text { heavy clay })
\end{aligned}
$$

with: $\mathrm{R}_{\text {adj }}=87.4 \%$ and $n=19$

The tunnel experiments also showed a reduction in $\mathrm{NH}_{3}$ losses from acidified slur- 


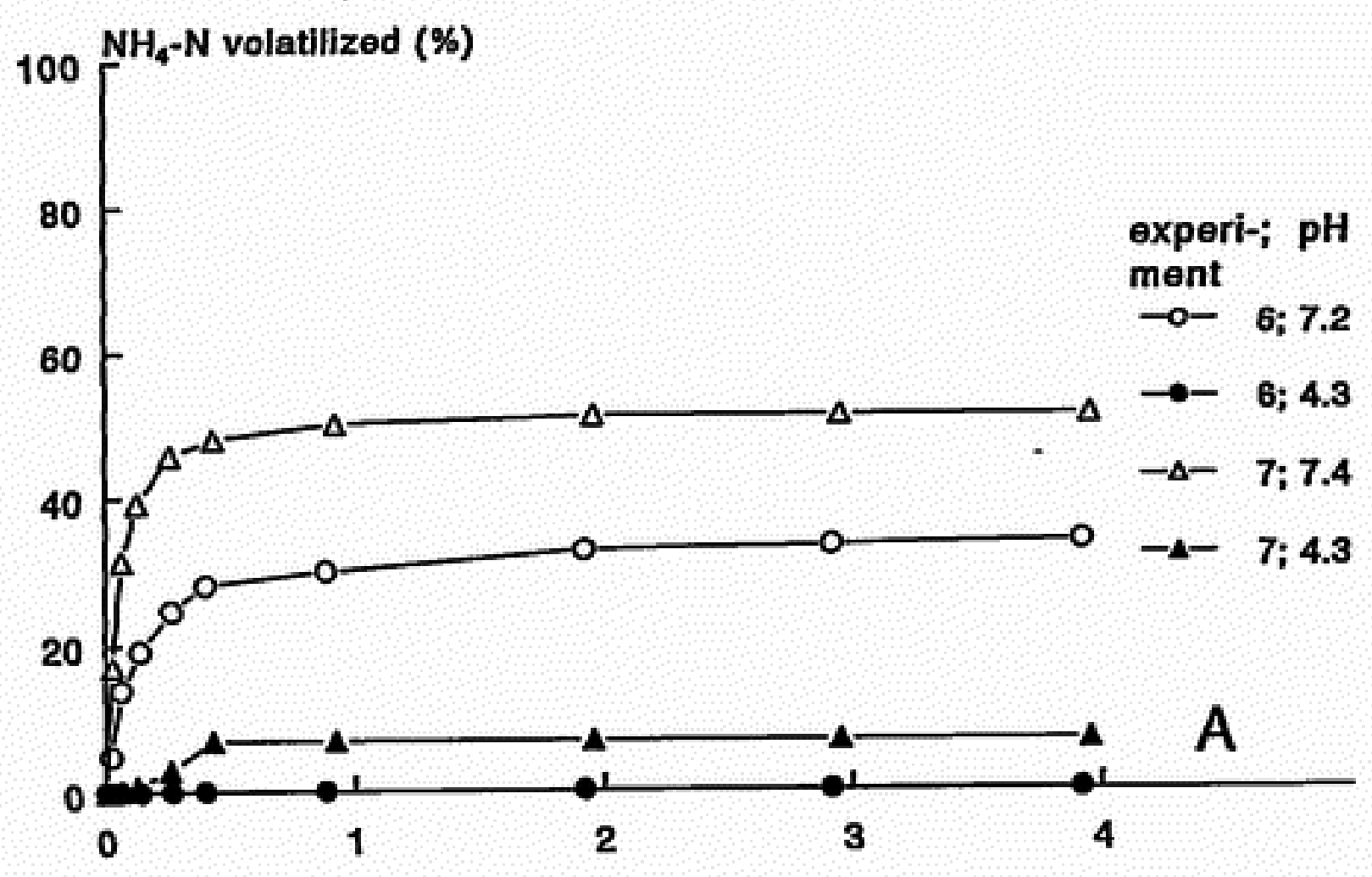

days after application

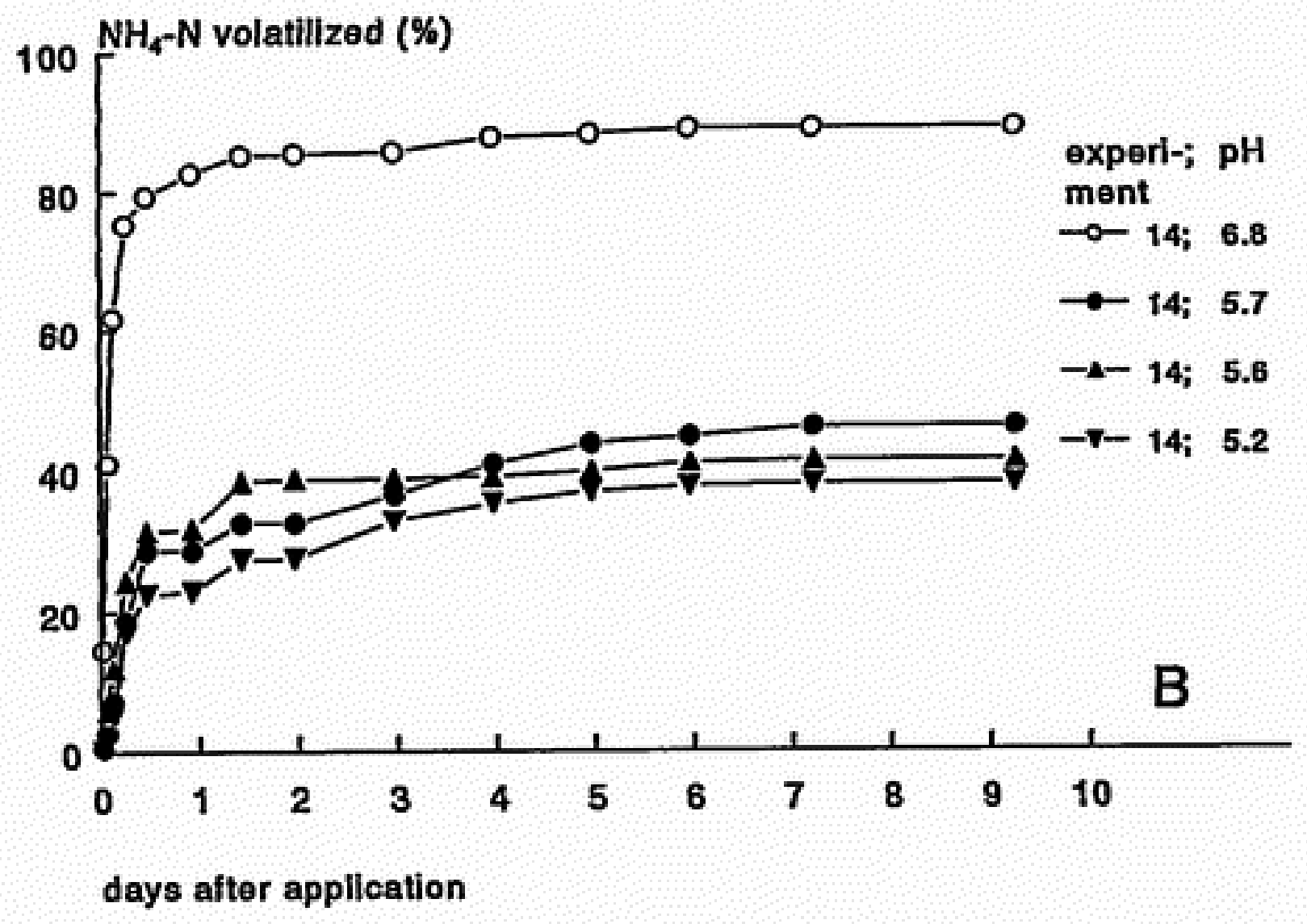

Figure 2. Pattem of $\mathrm{NH}_{3}$ volatilization in the mass balance experiments 6 and 7 (A) on sandy soil and experiment 13 (B) on heavy clay soil. 


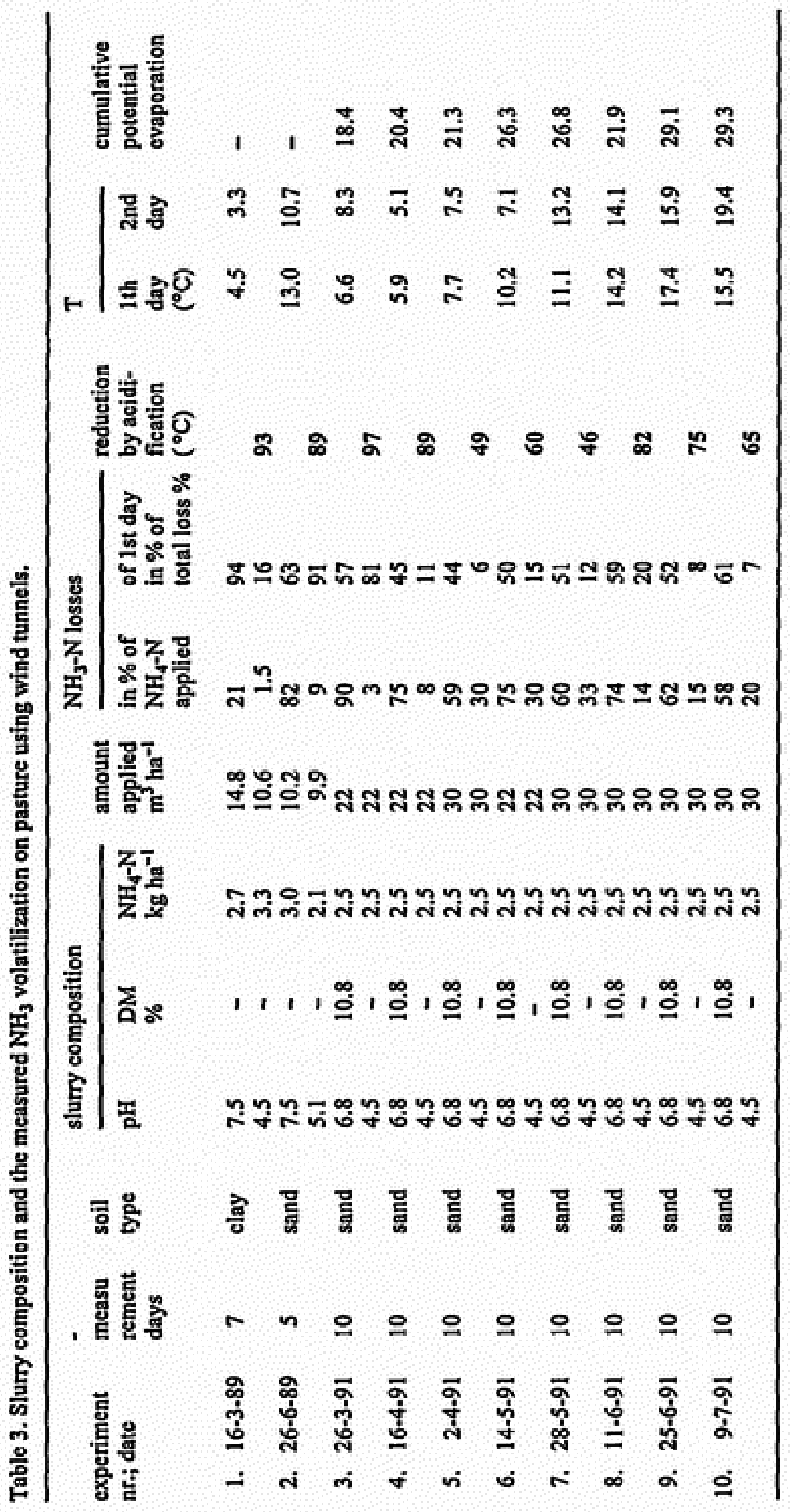




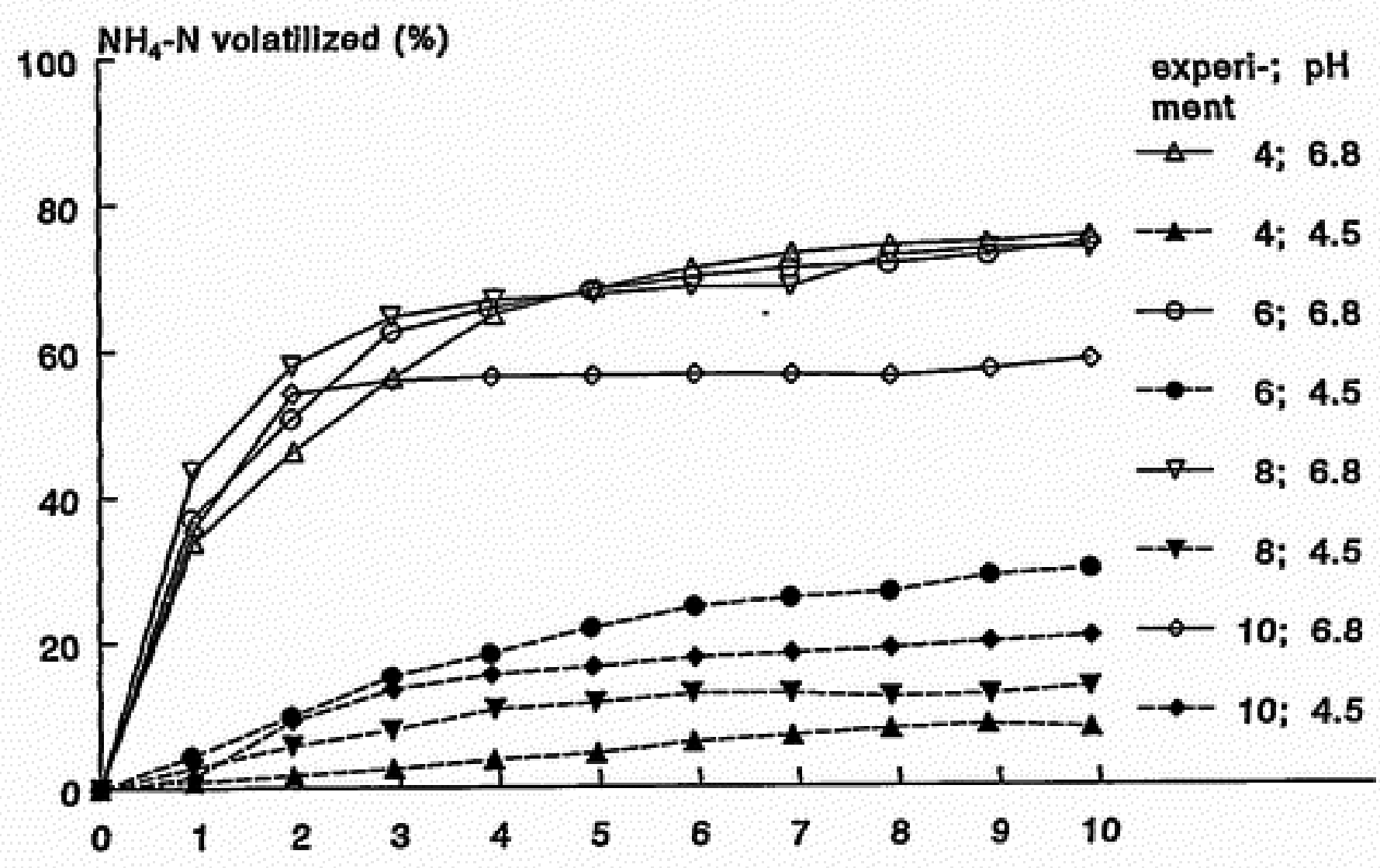

days after application

Figure 3. Pattern of $\mathrm{NH}_{3}$ volatilization in the wind tunnel experiments $4,6,8$ and 10 .

ry of 46 up to $97 \%$ to that of untreated slurry (Table 3 ). At $\mathrm{pH} \approx 4.5$ the mean reduction with the tunnel (73\%, range: $46-97 \%)$ was less, than with the mass balance method $(85 \%$, range: $69-99 \%)$. Furthermore, there was a difference in variation and volatilization continued longer in the tunnel experiments than in the mass balance experiments (Figures 2 and 3). On average 27\% (range: 6-91\%) and 68\% (range: $48-100 \%$ ) of the total $\mathrm{NH}_{3}$ loss was measured during the first and up to the fourth day, respectively.

Surprisingly, \% $\mathrm{NH}_{4}$-loss on day one was not significantly related to $\left(\mathrm{NH}_{3}\right)_{\mathrm{g}}$ or any weather parameter. This is probably due to the low losses on day one and the constant initial pH of the slurry. Also, \% $\mathrm{TNH}_{4}$-loss was not related to $\left(\mathrm{NH}_{3}\right)_{\mathrm{g}}$, but only slightly to the 10-day cumulative $\mathrm{E}_{\mathrm{p}}\left(\operatorname{cumE}_{\mathrm{p}} 10, \mathrm{~mm}\right)$ :

$$
\% \mathrm{TNH}_{4} \text {-loss }=0.565( \pm 0.097) \times \text { cumE }_{\mathrm{p}} 10 \quad\left(\mathrm{R}_{\mathrm{adj}}^{2}=23.6 \% \text { and } \mathrm{n}=8\right)
$$

for tunnel experiments 3-10 ( 1 and 2 are excluded because of differing experimental design).

\section{Changes in slurry pH}

In the mass balance experiments 12 and 13 , there was a rapid increase in $\mathrm{pH}$ immediately after slurry application, followed by a decrease in pH (Figure 4). After several hours a small rise in $\mathrm{pH}$ was observed.

In the tunnel experiments the $\mathrm{pH}$ of acidified slurry increased steadily (Figure 5). Experiment 10 showed the largest $\mathrm{pH}$ increase with c. 1.5 units. This did however 


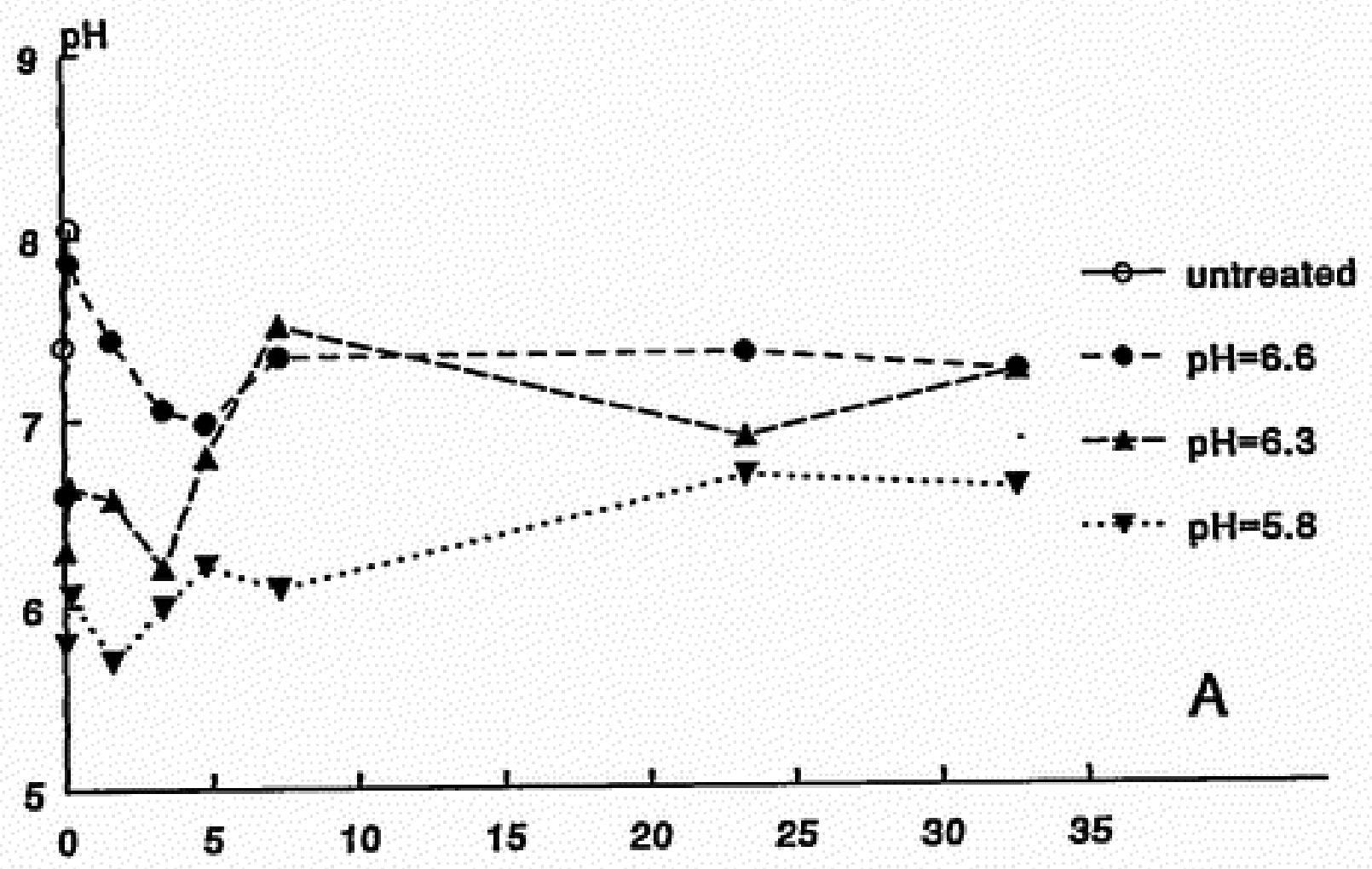

hours after appllcation

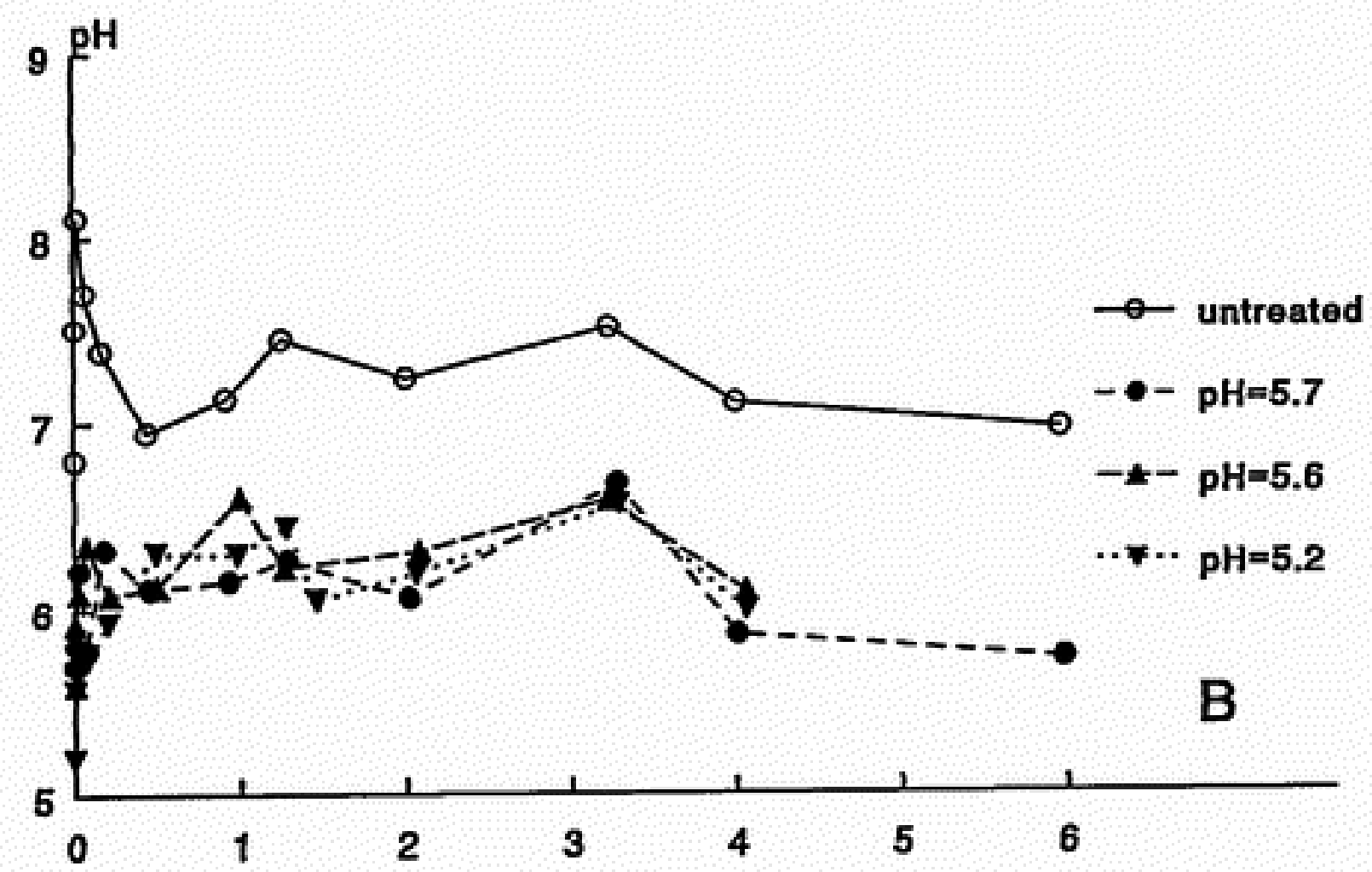

days after slurry application

Figure 4. Slurry pH after application on heavy clay soil in the mass balance experiments $12(\mathrm{~A})$ and 13(B). 


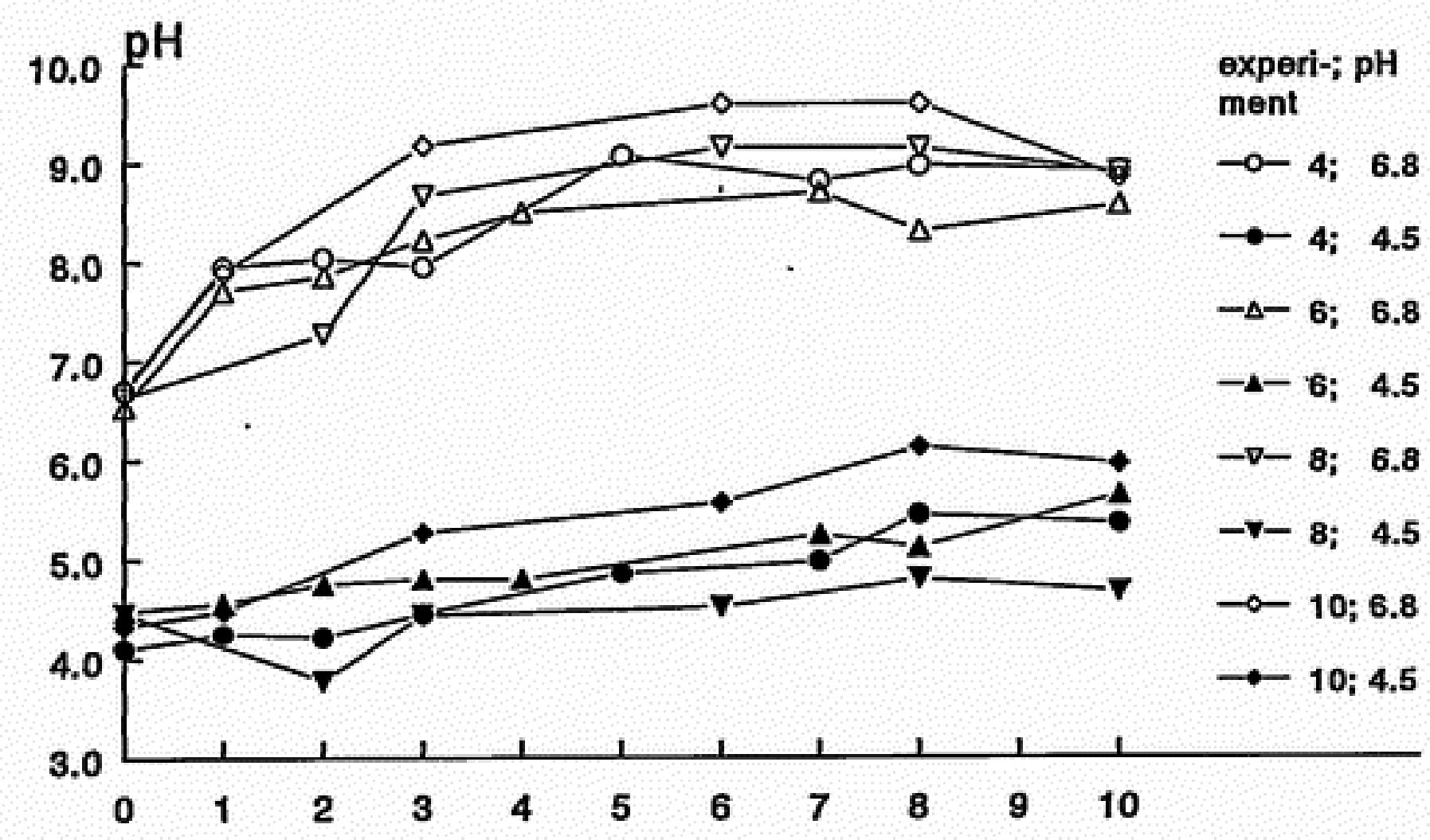

\section{days after application}

Figure 5 . The pH of acidified slurry after application on sandy soil in the wind tunnel experiments 4,6 , 8 and 10.

not result in the highest $\mathrm{NH}_{3}$ loss rate (Figure 3, experiment 6), despite the fact that cumE $\mathrm{E}_{\mathrm{p}} 10$ was also the largest (Table 3). Untreated slurry gave a sharp rise in $\mathrm{pH}$.

\section{Discussion}

\section{Effect of slurry acidification on $\mathrm{NH}_{3}$ loss}

Slurry acidification proved to be an efficient method of reducing $\mathrm{NH}_{3}$ losses. The reduction achieved strongly depended on initial slurry $\mathrm{pH}$ and air temperature (Figure 1), which was confirmed by regression analysis (Equation 5). Ammonia losses increased progressively with increasing $\mathrm{pH}$ and temperature and according to Equation $5 \mathrm{NH}_{3}$ losses increased also with cumE 4 .

Other experiments also showed marked reductions in $\mathrm{NH}_{3}$ loss due to acidification. In Northern Ireland, a slurry pH of 5.5, 6.0 and 6.5 resulted in a reduction of $\mathrm{NH}_{3}$ loss of $>85 \%$ (Frost et al., 1990), 90\% (Stevens et al., 1992) and 75\% (Stevens et al., 1992), respectively. Our experiments showed lower reductions for these pH values (Table 2), e.g. $\mathrm{pH}$ values of 4.5 to 5.0 were needed in the mass balance experiments - and even lower $\mathrm{pH}$ values in the tunnel experiments - to obtain similar reductions. This might be attributed to (i) the used measurement technique in Northern Ireland (discontinues measurements using ventilated enclosures) which underesti- 
mated $\mathrm{NH}_{3}$ loss rate (Frost et al., 1990) and (ii) the slightly higher temperature and evaporation in the Netherlands, which enhance $\mathrm{NH}_{3}$ loss as observed from Figure 1. Consequently lower $\mathrm{pH}$ values are needed to obtain the same levels of reduction. Also the smaller amount of slurry applied (e.g. Döhler, 1991) and the high slurry DM content may stimulate $\mathrm{NH}_{3}$ loss rate (Sommer \& Olesen, 1991), in comparison to other experiments on grassland (Pain et al., 1990; Frost et al., 1990; Stevens et al., 1989 \& 1992).

\section{Comparison of measuring techniques}

Two factors may account for the higher loss rates and the continuing loss (Figure 3) in the tunnel experiments. Firstly, differences in conditions in and outside the tunnel may stimulate $\mathrm{NH}_{3}$ volatilization. In tunnels any rainfall is intercepted and due to the continuous wind speed dew formation is possibly prevented and evaporation is possibly stimulated. These factors may lead to a lower infiltration of $\mathrm{NH}_{4}^{+}$into the soil and to an increase in $\left(\mathrm{NH}_{4}\right)_{\mathrm{aq}}$ and I. In a study of Ryden \& Lockyer (1985) no difference was found between mass balance and tunnel measurements with urea fertilizer provided that there was no rainfall and that wind speed in the tunnel was adjusted to wind speed outside the tunnel at a height of $0.25 \mathrm{~m}$. A lengthy $\mathrm{NH}_{3}$ loss was also observed by Pain et al. (1990) where the tunnels were only moved to an adjacent area of the plots if more than $2 \mathrm{~mm}$ of rain fell within a $24 \mathrm{~h}$ period.

Secondly, the rate of of slurry application in most wind tunnel experiments was 2 to 3 times higher than in the mass balance experiments. This difference may have also created a more favourable environment for a prolonged volatilization.

Whatever the cause of the differences between techniques may be it seems wise to move tunnels at least twice a day to adjacent spots with the same treatment and to adjust windspeed in the tunnel to local conditions.

\section{Changes in slurry $\mathrm{pH}$}

In the mass balance experiments 12 and 13 , where the slurry was acidified shortly before application (Figure 4), a rapid increase immediately after application of up to $1.2 \mathrm{pH}$ units was observed, especially for the higher $\mathrm{pH}$ values. This was caused by faster volatilization of $\mathrm{CO}_{2}$ than of $\mathrm{NH}_{3}$ (calculated with help of a chemical equilibria model; Keizer \& Van Riemsdijk, 1994), probably enhanced by the fact that the freshly prepared acidified slurry had not reached a chemical equilibrium and much carbonate remained. Similar rapid $\mathrm{pH}$ increases due to a faster volatilization of $\mathrm{CO}_{2}$ than of $\mathrm{NH}_{3}$ were observed in aeration experiments performed by Husted et al. (1991) with $\mathrm{HCl}$ treated slurry. The initial $\mathrm{pH}$ values of experiments 12 and 13 and probably also of experiment 11 , used in the regression analysis (Equation 4 \& 5) were underestimated in contrast to the initial pH at lower values (Figure 5). Consequently this results in a different behaviour of the heavy clay soil in Equations $4 \& 5$, since all the freshly prepared acidified slurry with high $\mathrm{pH}$ values was applied on this soil type. On the peat soil a pH increase of the applied slurry with respectively 0.5 and 1 unit after 1 and 4 days may have caused the different behaviour in Equations 4 \& 5 according to statistical analysis. This suggests some denitrification. However no $\mathrm{pH}$ or denitrification measurement data were available to confirm this. 
In addition it is possible that $\mathrm{NH}_{3}$ loss from acidified slurry at low application rates $\left(7-17 \mathrm{~m}^{3} \mathrm{ha}^{-1}\right)$ to grassland, is independent of soil type, since it was observed that the slurry made almost no direct contact with the soil surface in dense grass swards. Equations 4 \& 5, without the peat and heavy clay terms, may then be applied for all grassland soil types if the slurry is stable and almost free of carbonate, due to acidification.

In experiments $12 \& 13$ the rapid initial increase in $\mathrm{pH}$ is followed by a decrease during the next hours, due to $\mathrm{NH}_{3}$ loss (Figure 2B). Thereafter a slow increase in pH is observed, followed by a sharp decrease after day 3 . This increase in $\mathrm{pH}$ may be due to denitrification. Experiments conducted by Velthof \& Oenema (1993) with acidified cattle slurry of $\mathrm{pH} 4.5$ and 6.0 , surface applied to grassland, gave $\mathrm{N}_{2} \mathrm{O}-\mathrm{N}$ losses of $<0.1$ and $1.4 \%$ of applied nitrate. Taking into account that $\mathrm{N}_{2} \mathrm{O}$ losses may be accompanied by substantial $\mathrm{N}_{2}$ losses, then the $\mathrm{pH}$ increase of acidified slurry after the first hours (Figure 4) may result from denitrification. For $\mathrm{pH}$ values below 5.0 denitrification is probably lower, the more because $\mathrm{N}$ efficiency trials with acidified slurry of pH 4.5 (Schils; personal communication) showed an $\mathrm{N}$ recovery of applied mineral $\mathrm{N}$ which was similar to that of calcium-ammonium-nitrate fertilizer.

Treated slurry (Figure 5) in the tunnel experiments showed a slow uniform $\mathrm{pH}$ increase. This may be due to denitrification and or $\mathrm{pH}$ buffering by the soil.

\section{Target slurry $\mathrm{pH}$ for various conditions}

Because of the possible environmental impact of $\mathrm{NH}_{3}$ losses, legislative targets have been formulated for the reduction of $\mathrm{NH}_{3}$ losses from livestock, especially from manure application. In the Netherlands the target is $80 \%$ reduction by the year 2000 . This target can be met by slurry acidification as follows.

The measured mean total loss in the mass balance experiments of untreated slurry was $61 \%$. A loss of $12 \%$ is thus sufficient to meet the target reduction of $80 \%$. By rearranging Equation 6 for the sandy and clay soil, the required $\mathrm{pH}$ can be estimated from Equation 7 as a function of initial $\mathrm{NH}_{4}^{+}$concentration, average $\mathrm{T}$, cumE $\mathrm{p}_{\mathrm{p}} 4$ and maximum $\mathrm{NH}_{3}$ loss (12\%):

$$
\begin{aligned}
\mathrm{pH}= & \log (12)-\log \left(\left(3.61+1.58 \times \mathrm{cumE}_{\mathrm{p}} 4\right) *\left[\mathrm{NH}_{4}\right]\right)-11.117 \\
& +4507.053 /(\mathrm{T}+273.15)
\end{aligned}
$$

As discussed it is likely that there is no difference between the four grassland soil types in $\mathrm{NH}_{3}$ volatilization. Therefore Equation 7 is also used for peat and heavy clay soil. The $\mathrm{pH}$ needed to obtain the reduction target of $80 \%$ on grassland then ranges from 6.0 for an average temperature of $5^{\circ} \mathrm{C}$ and cumE 4 of $4 \mathrm{~mm}$, whereas it has to be 4.5 for an average temperature of $20^{\circ} \mathrm{C}$ and cumE ${ }_{p} 4$ of $16 \mathrm{~mm}$ (Figure 6).

\section{Conclusion}

Acidification of cattle slurry gave a marked reduction in $\mathrm{NH}_{3}$ losses from surface applied slurry, irrespective of the method employed to measure $\mathrm{NH}_{3}$ volatilization.

Key factors in determining the $\mathrm{NH}_{3}$ loss rate are $\mathrm{T}, \mathrm{pH}$ and potential evaporation. 


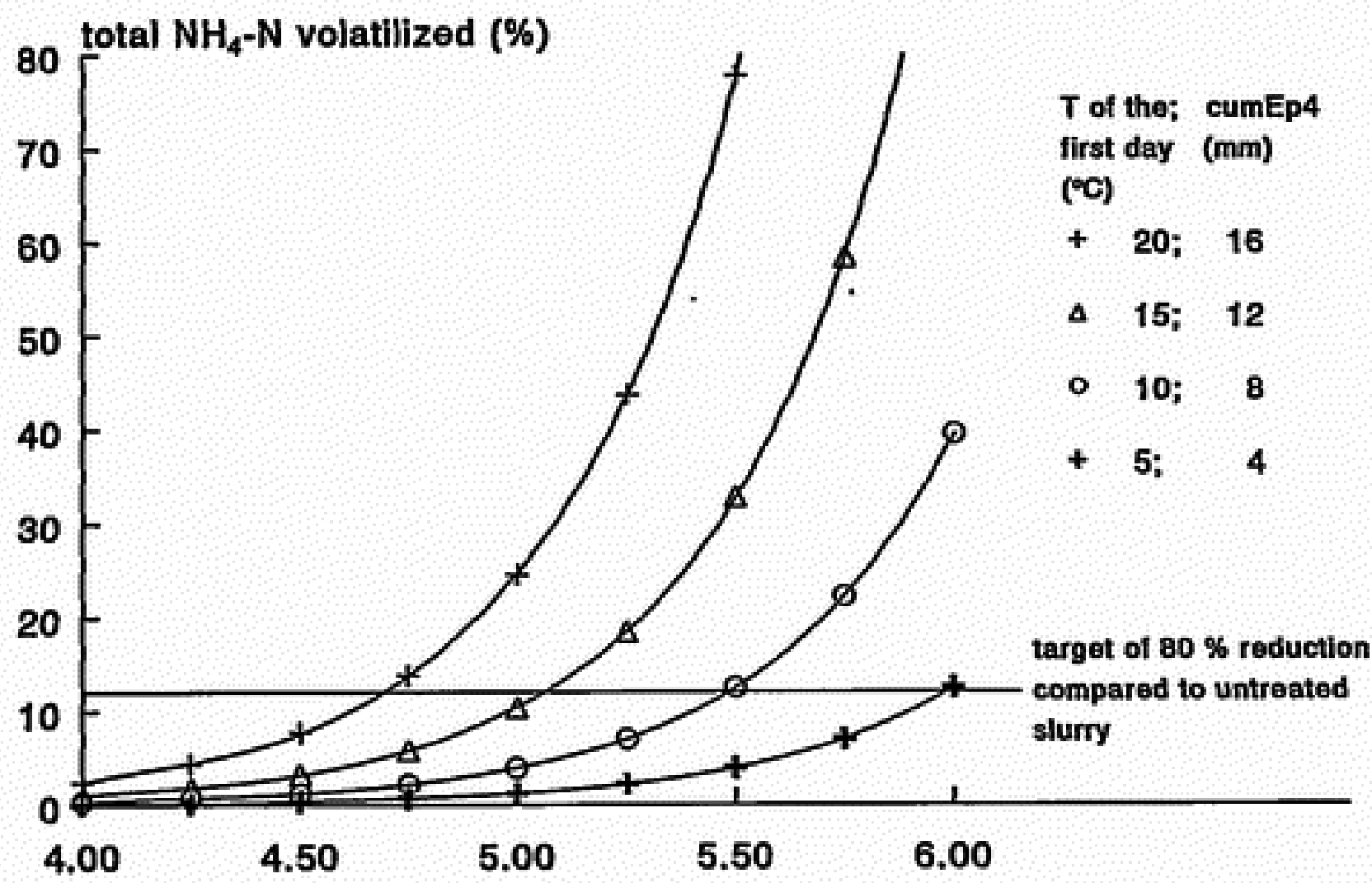

slurry $\mathrm{pH}$

Figure 6. Expected rate of loss in total $\mathrm{NH}_{3}$ for different $\mathrm{pH}$, cumulative evaporations and temperature values according to Equation 5 for an initial $\mathrm{NH}_{4}^{+}$concentration of $0.157 \mathrm{M}$, assuming that peat and heavy clay soil do not differ from sand and clay soil.

To obtain a low volatilization by acidification all the carbonate should be removed from the slurry (via $\mathrm{CO}_{2}$ ). It was hypothesized that the $\mathrm{pH}$ required to obtain a certain reduction in $\mathrm{NH}_{3}$ loss was independent of the grassland soil type at the application levels used in the experiments, because of the limited contact of slurry with the soil. At low temperatures and water evaporation a $\mathrm{pH}$ of about 6.0 is needed to achieve a reduction in $\mathrm{NH}_{3}$ loss of $80 \%$ of that of untreated slurry. At high temperatures and water evaporation this is approximately 4.5 .

The measured rise in $\mathrm{pH}$ in the experiments with acidified slurry after the initial hours after application, is probably caused by denitrification of slurry with a $\mathrm{pH}$ between 5.0 and 6.0 .

\section{Acknowledgements}

Thanks are due to Kemira, DSM and the Research Program on Animal manure and Ammonia emission for their financial support. The authors express their special appreciation and gratitude to M.A. Bruins, A. Hol, H. Gunnink, H.E. Selis and S. Tjalma, for their assistance in field data collection and in data processing. 


\section{References}

Apsimon H.M., M. Kruse \& J.N.B. Bell, 1987. Ammonia emissions and their role in acid deposition. Atmospheric Environment 21: 1939-1946.

Bictz, J.A., 1974. Micro-Kjeldahl analysis by an improved automated ammonia determination following manual digestion. Analytical Chemistry 46: 1617-1618.

Bless H.G., R. Beinhauer \& B. Sattlemacher, 1991. Ammonia emission from slurry applied to wheat stubble and rape in North Germany. Journal of Agricultural Science (Cambridge) 117: 225-231.

Buijsman E., H.F.M. Maas \& W.A.H. Asman, 1987. Anthropogenic NH3 emissions in Europe. Atmospheric Environment 21: 1009-1022.

Bussink D.W. \& M.A. Bruins, 1992. Reduction in ammonia volatilization using different slurry application techniques on grassland. (In Dutch). Meststoffen 1992: 31-36.

Dasgupta P.K. \& S. Dong, 1986. Solubility of ammonia in liquid water and generation of trace levels of standard gaseous ammonia. Atmospheric Environment 20: 565-570.

Denmead O.T., 1983. Micrometeorological methods for measuring gaseous losses of nitrogen in the field. In: J.R. Freney \& J.R. Simpson (Eds.). Gaseous loss of nitrogen from plant-soil Systems. Developments in Plant and Soil Science, Volume 9. Martinus Nijhoff, The Hague, pp. 133-157.

Döhler H., 1991. Laboratory and field experiments for estimating ammonia losses from pig and cattle slurry following application. In: V.C. Nielsen, J.H. Voorburg \& P.L'Hermite (Eds.). Odour and ammonia emissions from livestock farming. Elsevier Applied Science, London, pp. 132-141.

Emerson K., R.C. Russo, R.E. Lund \& R.V. Thurston, 1975. Aqueous ammonia calculations: Effect of $\mathrm{pH}$ and temperature. Journal of Fisheries Research Board Canada 32: 2379-2383.

Frost J.P., R.J. Stevens \& R.J. Laughlin, 1990. Effect of separation and acidification of cattle slurry on ammonia volatilization and on the efficiency of slurry nitrogen for herbage production. Journal of Agricultural Science (Cambridge) 115: 49-56.

Horiacher D. \& H. Marschner, 1990. Schätzrahmen zur Beurteilung von Ammoniakverluste nach Ausbringung von Rinderflüssigmist. Zeitschrift für Pflanzernāhrung und Bodenkunde 153: 107-115.

Husted S., L.S. Jensen \& S.S. Jф̣rgensen, 1991. Reducing ammonia loss from cattle slurry by the use of acidifying additives: the role of the buffer system. The Journal of Science of Food and Agriculture 57: 335-349.

Keizer M.G. \& W.H. van Riemsdijk, 1994. A computer program for the calculation of speciation and transport in soil-water systems. Department of Soil Science and Plant Nutrition, Wageningen Agricultural University, 21 pp.

Koorevaar P, G. Menelik \& C. Dirksen C., 1983. Elements of soil physics. Elsevier Amsterdam, 288 pp.

Lockyer R., 1984. A system for the measurement in the field of losses of ammonia through volatilisation. Journal of Science of Food and Agriculture 35: 837-848.

Mulder E.M. \& J.F.M. Huijsmans, 1994. Reduction of ammonia emission during slurry application. Summary of measurements by the DLO Field Service in 1990-1993. (In Dutch). DLO, Wageningen, $71 \mathrm{pp}$.

Pain B.F,, V.R. Philips, C.R. Clarkson \& J.V. Klarenbeek, 1989. Loss of nitrogen through ammonia volatilisation during and following the application of cattle slurry to grassland. Journal of Science of Food and Agriculiure 47: 1-12.

Pain B.F., R.B. Thompson, Y.J. Rees \& J.H. Skinner, 1990. Reducing gaseous losses of nitrogen from cattle slurry applied to grassland by the use of additives. Journal of Science of Food and Agriculture 50: $141-153$.

Roclofs J., A. Kempers, A. Houdijk \& J. Jansen, 1985. The effect of airbome ammonium sulphate on Pinus nigra var. maritima in the Netherlands. Plant and Soil 84: 45-56.

Ryden J.C. \& R. Lockyer, 1985. Evaluation of a system of wind tunnels for field studies of ammonia loss from grassland through volatilisation. Journal of Science of Food and Agriculture 36: 781-788.

Schlesinger W.H. \& A.E. Hartley, 1992. A global budget for atmospheric $\mathrm{NH}_{3}$. Biochemistry 15: 191-211.

Sommer S.G., J.E. Olesen \& B.T. Christensen, 1991. Effects of temperature wind speed and air humidity on ammonia volatilization from surface applied cattle slurry. Journal of Agricultural Science (Cambridge) 117: 91-100. 
Sommer S.G. \& J.E. Olesen, 1991. Effects of dry matter content and temperature on ammonia loss from surface-applied cattle slurry. Journal of Environmental Quality 20: 679-683.

Stevens R.J., R.J. Laughlin \& J.P. Frost, 1989. Effect of acidification with sulphuric acid on the volatilization of ammonia from cow and pig slurries. Journal of Agricultural Science (Cambridge) 113: 383-389.

Stevens R.J., R.J. Laughlin \& J.P. Frost, 1992. Effects of separation, dilution, washing and acidification on ammonia volatilization from surface-applied cattle slurry. Journal of Agricultural Science (Cambridge) 119: 383-389.

Thompson R.B., J.C. Ryden \& D.R. Lockyer, 1987. Fate of nitrogen in cattle slurry following surface application or injection into grassland. Journal of Soil Science 38: 689-700.

Van der Meer H.G., R.B. Thompson, P.J.M. Snijders \& J.H. Geurink, 1987. Utilization of nitrogen from injected and surface-spread cattle slurry applied to grassland. In: H.G. Van der Meer, R.J. Unwin, T.A. Van Dijk \& G.C. Ennik (Eds.) Animal manure on grassland and fodder crops. Fertilizer or waste? Developments in Plant and Soil Science, Volume 30. Martinus Nijhoff, The Hague, pp. 17-25.

Van der Molen J., H.G. Van Faassen, M.Y. Leclerc, R. Vriesema \& W.J. Chardon, 1990. Ammonia volatilization from arable land after application of cattic slurry. I Field estimates. Netherlands Journal of Agricultural Science 38: 45-58.

Vanysek P., 1989. Activity coefficients of acids, bases and salt. D171-D172. In: R.C. Weast (Eds.), D.R. Lide, M.J. Astle \& W.H. Beyer. Handbook of Chemistry and Physics. CRC Press Inc., Boca Raton.

Velthof G.L. \& O. Oenema, 1993. Nitrous oxide flux from nitric-acid-treated cattle slurry applied to grassland under semi-controlled conditions. Netherlands Journal of Agricultural Science 41: 81-93.

Weatherburn M.W., 1967. Phenol-hypochlorite reaction for the determination of ammonia. Analytical Chemistry 39: 971-974. 